\title{
Effect of Seed Treatment and Sprays Formulations on Morpho- Physiological Traits of Bt Cotton and their Impact on Dynamics of Sucking Pests
}

\author{
Vijayakumar Savanur, S.B. Patil and Ganesha Halikatti* \\ ${ }^{1}$ Department of Agricultural Entomology, University of Agricultural Sciences, Dharwad, \\ Karnataka (India) \\ *Corresponding author
}

\section{A B S T R A C T}

\section{Keywords}

Seed treatment, Sprays formulations, Morphophysiological, Bt Cotton, Dynamics, Sucking Pests.

\section{Article Info}

Accepted: 26 June 2018 Available Online: 10 July 2018
Field experiment carried out at ARS, Dharwad during 2013-14 to study the effect of seed treating chemical and spray formulations on morpho-physiological traits and their impact on sucking pests incidence in Bt cotton. Seed treatment with Imidacloprid 70WS registered higher seedling vigour index of 1089.00 as compared to 1053.00 in Thiamethoxam 35FS. Further, highest leaf specific weight of $0.043 \mathrm{~g} / \mathrm{cm}^{2}$ was registered in Imidacloprid $70 \mathrm{WS}$ treated seeds were sown and sprayed with Imidacloprid 17.8SL. Similarly, Imidacloprid 17.80SL was sprayed as subsequent sprays registered higher relative water content of 88.87 per cent. Among the treatments, seed treatment with Imidacloprid 70WS followed by Imidacloprid $17.8 \mathrm{SL}$ spray recorded higher chlorophyll content $(1.31 \mathrm{mg} / \mathrm{g})$ followed by seed treatment with Thiamethoxam 35FS and Imidacloprid 17.80SL spraying (1.30 $\mathrm{mg} / \mathrm{g}$ ). Initially, population of thrips and leaf hopper was on lower side and there was gradual increase in the pest population after the subsequent sprays with Imidacloprid 17.80SL.

\section{Introduction}

Cotton (Gossypium hirsutum L.) is an important cash crop in India and plays a significant role in the national economy, contributing about Rs. 360 billion towards export income and four per cent of the GDP. In the light of large scale adoption of technology, pest profile in Bt cotton has witnessed unprecedented change. The very reasons attributed for these dramatic change in the pest situation is multiplicity of $\mathrm{Bt}$ cotton genotypes available for cultivation, changed cultivation practices and influence of abiotic factors in the form of climatic change. Hitherto unknown minor pests are emerging as major pests viz., thrips, leaf hoppers, mealy bug, mirid bug, flower bud midge ${ }^{[12]}$.

The most common practice to manage these sucking pests in cotton is seed treatment with imidacloprid 70WS or Thiamethoxam 35FS followed by spraying with insecticides. The seed treatment chemicals can have growth 
enhancing effect of cotton plant, that makes the plant vulnerable for sucking pests damage which intern warrants repeated chemical interventions. Further it was observed that repeated use of selective insecticides, particularly insecticides may have impact on plant morpho physiological traits viz., plant vigour, leaf area, specific leaf weight, nitrate reductase activity, chlorophyll content, photosynthetic rate, transpiration, stomatal conductance and leaf moisture content ${ }^{[11]}$.

Quantitative rise in the yield level of crops due to pest control certainly cannot rule out that application of chemicals in pest control has not affected the metabolic path ways such as photosynthesis and respiration rate $^{[3]}$. The imidacloprid could growth enhancing effects on cotton hybrid by increasing total leaf area.

Imidacloprid applied plants shown increased level of photo synthesis and higher value of Chlorophyll Fluorescence yield measured two days after the application of imidacloprid. Further, Imidacloprid treated plants suffered less temperature stress. These results were supported by findings of reduced glutathione reduced in imidacloprid treated plants indicating that untreated plants experiencing more stress, necessitating the activation of this defense mechanism ${ }^{[6]}$. Further, thiamethoxam when applied as seed treatment, increases plant vigour, which resulted in strong stand establishment and higher yield ${ }^{[5]}$. According to ${ }^{[13]}$, thiamethoxam influenced the early growth of plants by enhancing root development, increasing the concentration of total soluble protein, reduced nitrate reductase activity and increased phenylamine ammonia lyase activity.

Variation in the effect of insecticidal compound exist between various classes of chemicals used for insect control ${ }^{[8]}$. In addition, the rate and number of pesticidal application may alter the compound effect ${ }^{[7]}$. Investigations on these issues are normally investigations restricted to laboratory due to lack of accurate portable instruments which can measure physiological parameters under field conditions. With this background in view the effort has been made to understand phytotonic nature of insecticides which are commonly used for pests control in cotton ecosystem and their impact on morphophysiological traits and sucking pests incidence.

\section{Materials and Methods}

The field experienced was carried out at Agricultural Research Station, Dharwad Farm, Karnataka during 2013-14 to study the effect of seed treating chemical and spray formulations on morpho-physiological traits and their impact on sucking pests incidence viz., thrips and leaf hoppers in Bt cotton. For the purpose, Bunny Bt BG-II hybrid cotton treated with Imidacloprid 70WS and Thiamethoxam 35FS and untreated Bunny Bt seed $\mathrm{s}$ were sown in a independent plot size of $5.4 \mathrm{~m} \mathrm{x} 3.6 \mathrm{~m}$ each with a spacing of $90 \mathrm{~cm} \times$ $60 \mathrm{~cm}$ between rows and plant respectively. All recommended agronomical practices were followed in order to have good crop staid. The impact of sprays on morph physiological traits and the pests incidence was studied by spraying the crop with four pesticide molecules and was compared with untreated check. The chemical interventions were made at 35 DAS with high volume sprayer and were continued for four times based on economic threshold level of pests incidence. The experiment comprised of fifteen treatments with two replications. Five plants in each treatment were selected randomly from top, middle and bottom leaves of plants were considered for recording observations. The mean data of all four sprays ware considered to study the impact of sprays on morpho physiological the traits viz., vigour index, leaf moisture content (RWC), specific leaf weight (SLW), chlorophyll content and impact on sucking pest populations which were 
ascertained after each sprays. The methodology followed for each morpho physiological traits were as detailed here under.

\section{Vigour index}

Vigour index was computed 12 DAS using the formula and expressed in number ${ }^{[1]}$.

Vigour Index $=$ Germination\% $\mathrm{x}$ (shoot length

+ Root length) $\mathrm{cm}$

\section{Leaf moisture (Relative water content)}

The relative water content was estimated based as per the method developed by ${ }^{[4]}$.

\section{Results and Discussion}

\section{Seedling vigour index}

The result with respect seeding viguor was as influenced by seed treatments and subsequent sprays revealed significant variation. Among the treatments, seed treatment with Imidadoprod 70 WS registered higher seeding vigour index of 1089.00 as compared to 1053.00 in Thiamethoxam 35 FS seed treatments. On the contrary, lowest seeding vigour index of 909.5 was registered with untreated control. These findings are in conformity with ${ }^{[11]}$, who reported higher seeding vigour index of 1002, where seeds were treated with imidacloprid tows (Table 2).

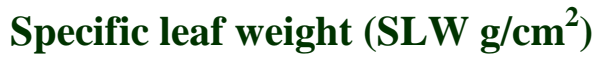

The data revealed significant variation among the treatments with regards to the impact of seed treating chemical and subsequent sprays. Among the treatments, highest leaf specific weight of $0.043 \mathrm{~g} / \mathrm{cm}^{2}$ was registered in the treatment where Imidacloprid 70WS treated seeds were sown and the crop subsequently sprayed with Imidacloprid 17.8SL, this was followed by Thiamethoxam 35FS treated seeds sown crop continued with spraying of Imidacloprid $17.80 \mathrm{SL}\left(0.038 \mathrm{~g} / \mathrm{cm}^{2}\right)$ and Imidacloprid 17.80 SL spray alone $(0.036$ $\mathrm{g} / \mathrm{cm}^{2}$ ). Further SLW increased with increase in number of sprays except in untreated control. The result obtained are in line with the findings of ${ }^{[11]}$ who reported positive impact of seed treatment with imidacloprid tows on specific leaf weight in DHB-105 non Bt Cotton (Table 1).

\section{Relative water content (RWC \%)}

Among the treatments, where Imidacloprid 17.80SL was sprayed as subsequent sprays registered higher relative water content of 88.87 per cent as compared to 88.47 per cent in seed treatment with Thiamethoxam 35FS and continued with Imidacloprid 17.80SL spraying. The higher RWS in the respective treatments was due to enhanced photosynthetic activity and higher chlorophyll content of foliage. These findings corroborate with the results of ${ }^{[9]}$ who reported higher RWC in plants when sprayed with systemic fungicides viz., cyproconazole and propiconazole $(80 \%)$ (Table 1).

\section{Total chlorophyll content (fresh weight)}

The data on chlorophyll content revealed significant variation among the different treatments. Among the treatments, seed treatment with Imidacloprid 70 WS followed by Imidacloprid $17.80 \mathrm{SL}$ subsequent sprays registered higher chlorophyll content of 1.31 $\mathrm{mg} / \mathrm{g}$ fresh weight followed by seed treatment Thiamethoxam 35FS continued with spraying of Imidacloprid 17.80SL spray done (1.30 $\mathrm{mg} / \mathrm{g}$. fr.wt). The higher chlorophyll content recorded in the respective treatment was mainly due to Imidacloprid $17.8 \mathrm{SL}$ interactions. The total chlorophyll content known to influence the rate of photosynthesis which intern influences the plant growth and development of cotton plant. 
Table.1 Effect of seed treatment and sprays formulations on morpho-physiological traits of Bt cotton and their impact on dynamics of sucking pests

\begin{tabular}{|c|c|c|c|c|c|c|c|c|c|c|c|c|c|c|c|c|c|c|c|c|}
\hline \multirow[t]{2}{*}{ Treatments } & \multicolumn{4}{|c|}{ Specific leaf weight $\left(\mathrm{g} / \mathrm{cm}^{2}\right)$} & \multicolumn{4}{|c|}{$\begin{array}{l}\text { Relative water content } \\
(\%)\end{array}$} & \multicolumn{4}{|c|}{$\begin{array}{l}\text { Total chlorophyll } \\
\text { (mg/g fresh weight) }\end{array}$} & \multicolumn{4}{|c|}{ Population of Thrips tabaci } & \multicolumn{4}{|c|}{$\begin{array}{l}\text { Population of Amrasca } \\
\text { devastatus }\end{array}$} \\
\hline & ST-1 & ST-2 & ST-3 & Mean & ST-1 & ST-2 & ST-3 & Mean & ST-1 & ST-2 & ST-3 I & Mean & ST-1 & ST-2 & ST-3 & Mean & ST-1 & ST-2 & ST-3 & Mean \\
\hline $\begin{array}{l}\text { Imidacloprid } \\
\text { 17.8 SL }\end{array}$ & $\begin{array}{c}0.043 \\
(0.201)\end{array}$ & $\begin{array}{c}0.038 \\
(0.187)\end{array}$ & $\begin{array}{c}0.036 \\
(0.182)\end{array}$ & $\mathbf{0 . 0 3 9}$ & 88.87 & 88.46 & 88.47 & 88.60 & 1.31 & 1.30 & 1.28 & 1.30 & $\begin{array}{l}14.83 \\
(3.85)\end{array}$ & $\begin{array}{l}14.43 \\
(3.80)\end{array}$ & $\begin{array}{l}14.19 \\
(3.77)\end{array}$ & 14.48 & $\begin{array}{c}2.73 \\
(1.65)\end{array}$ & $\begin{array}{c}2.58 \\
(1.61)\end{array}$ & $\begin{array}{c}2.68 \\
(1.64)\end{array}$ & 2.66 \\
\hline $\begin{array}{l}\text { Dimethoate } 35 \\
\text { EC }\end{array}$ & $\begin{array}{c}0.029 \\
(0.158)\end{array}$ & $\begin{array}{c}0.033 \\
(0.172)\end{array}$ & $\begin{array}{c}0.033 \\
(0.172)\end{array}$ & 0.032 & 87.14 & 86.42 & 84.66 & 86.07 & 1.21 & 1.21 & 1.21 & 1.21 & $\begin{array}{l}13.07 \\
(3.62)\end{array}$ & $\begin{array}{l}11.48 \\
(3.39)\end{array}$ & $\begin{array}{l}11.02 \\
(3.32)\end{array}$ & 11.86 & $\begin{array}{c}2.28 \\
(1.51)\end{array}$ & $\begin{array}{c}1.93 \\
(1.39)\end{array}$ & $\begin{array}{c}2.13 \\
(1.46)\end{array}$ & 2.11 \\
\hline $\begin{array}{l}\text { Acetamiprid } 20 \\
\text { SP }\end{array}$ & $\begin{array}{c}0.034 \\
(0.175)\end{array}$ & $\begin{array}{c}0.032 \\
(0.169)\end{array}$ & $\begin{array}{c}0.029 \\
(0.158)\end{array}$ & 0.032 & 86.44 & 85.12 & 86.86 & 86.14 & 1.17 & 1.16 & 1.19 & 1.17 & $\begin{array}{l}12.27 \\
(3.50)\end{array}$ & $\begin{array}{l}10.47 \\
(3.24)\end{array}$ & $\begin{array}{c}9.47 \\
(3.08)\end{array}$ & 10.74 & $\begin{array}{c}1.85 \\
(1.36)\end{array}$ & $\begin{array}{c}1.67 \\
(1.29)\end{array}$ & $\begin{array}{c}1.37 \\
(1.17)\end{array}$ & 1.63 \\
\hline $\begin{array}{l}\text { Lecanicillium } \\
\text { lecanii }\end{array}$ & $\begin{array}{c}0.031 \\
(0.165)\end{array}$ & $\begin{array}{c}0.026 \\
(0.146)\end{array}$ & $\begin{array}{c}0.027 \\
(0.150)\end{array}$ & 0.028 & 85.62 & 83.23 & 82.64 & 83.83 & 1.15 & 1.15 & 1.12 & 1.14 & $\begin{array}{l}10.13 \\
(3.18)\end{array}$ & $\begin{array}{c}9.21 \\
(3.03)\end{array}$ & $\begin{array}{l}10.52 \\
(3.24)\end{array}$ & 9.95 & $\begin{array}{c}2.37 \\
(1.54)\end{array}$ & $\begin{array}{c}1.87 \\
(1.37)\end{array}$ & $\begin{array}{c}1.97 \\
(1.40)\end{array}$ & 2.07 \\
\hline Water spray & $\begin{array}{c}0.028 \\
(0.154)\end{array}$ & $\begin{array}{c}0.026 \\
(0.146)\end{array}$ & $\begin{array}{c}0.024 \\
(0.137)\end{array}$ & 0.026 & 78.61 & 78.26 & 76.76 & 77.88 & 1.15 & 1.12 & 1.16 & 1.14 & $\begin{array}{l}27.58 \\
(5.25)\end{array}$ & $\begin{array}{l}28.99 \\
(5.38)\end{array}$ & $\begin{array}{l}30.37 \\
(5.51)\end{array}$ & 28.98 & $\begin{array}{c}2.80 \\
(1.67)\end{array}$ & $\begin{array}{c}2.98 \\
(1.73)\end{array}$ & $\begin{array}{c}3.78 \\
(1.94)\end{array}$ & 3.19 \\
\hline \multirow[t]{2}{*}{ Mean } & 0.033 & 0.031 & 0.030 & 0.031 & 85.34 & 84.30 & 83.88 & 84.50 & 1.20 & 1.19 & 1.19 & 1.19 & 15.58 & 14.92 & 15.11 & 15.20 & 2.41 & 2.21 & 2.39 & 2.33 \\
\hline & \multicolumn{2}{|c|}{ SEm \pm} & \multicolumn{2}{|c|}{ CD } & \multicolumn{2}{|c|}{ SEm \pm} & \multicolumn{2}{|c|}{ CD } & \multicolumn{2}{|c|}{ SEm \pm} & \multicolumn{2}{|c|}{ CD } & \multicolumn{2}{|c|}{ SEm \pm} & \multicolumn{2}{|c|}{ CD } & \multicolumn{2}{|c|}{ SEm \pm} & \multicolumn{2}{|c|}{ CD } \\
\hline $\begin{array}{l}\text { Seed treatment } \\
(\mathrm{T})\end{array}$ & \multicolumn{2}{|c|}{0.006} & \multicolumn{2}{|c|}{ NS } & \multicolumn{2}{|c|}{1.11} & \multicolumn{2}{|c|}{ NS } & \multicolumn{2}{|c|}{0.02} & \multicolumn{2}{|c|}{ NS } & \multicolumn{2}{|c|}{0.46} & \multicolumn{2}{|c|}{ NS } & \multicolumn{2}{|c|}{0.12} & \multicolumn{2}{|c|}{ NS } \\
\hline Insecticide (I) & \multicolumn{2}{|c|}{0.007} & \multicolumn{2}{|c|}{0.020} & \multicolumn{2}{|c|}{2.13} & \multicolumn{2}{|c|}{6.56} & \multicolumn{2}{|c|}{0.03} & \multicolumn{2}{|c|}{0.09} & 0. & 59 & 1.8 & 83 & & 14 & & 45 \\
\hline $\begin{array}{l}\text { Interaction } \\
(\mathrm{TxI})\end{array}$ & & 12 & $\mathrm{~N}$ & & & 68 & & JS & & .05 & & NS & & 03 & & $\mathrm{JS}$ & & 25 & & NS \\
\hline
\end{tabular}

ST-1= Imidacloprid 70 WS, ST-2= Thiamethoxam 30 FS and ST-3= Untreated Seeds

Table. 2 Effect of seed treatment on seedling vigour index

\begin{tabular}{|c|c|c|}
\hline Treatment & Dose & Seedling Vigour \\
\hline Imidacloprid 70 WS & $10 \mathrm{~g} / \mathrm{kg}$ seeds & 1089.00 \\
\hline Thiamethoxam 30 FS & $5 \mathrm{~g} / \mathrm{kg}$ seeds & 1053.00 \\
\hline Untreated Seeds & --- & 909.50 \\
\hline Mean & & $\mathbf{1 0 1 7 . 1 6 7}$ \\
\hline Em \pm & & $\mathbf{3 2 . 3 1}$ \\
\hline CD & $\mathbf{9 8 . 2 9}$ \\
\hline
\end{tabular}


The enhancement in total chlorophyll content in plant due to continuous spraying with Imidacloprid 17.8SL corroborate with the findings of ${ }^{[11]}$, who reported higher chlorophyll content in imidacloprid tows treated DHH-11 cotton genotype. Further, ${ }^{[10]}$ also reported higher chlorophyll content in plant system that influenced rate photosynthesis activity and growth in cotton plants.

\section{Impact on sucking pest incidence}

The observation recorded on the impact of seed treatment followed by their respective sprays on the sucking pests incidence revealed the significant variation among the treatments. Although, the incidence of sucking pests population viz., thrips and leaf hopper was on lower side initially, gradual increase in the pest population was observed after the subsequent sprays with Imidacloprid 17.80SL. On the contrary, in the treatments where with or without seed treatments followed by sprays with Dimethoate 35FS, Acetameprid 20SP and Lacanicellium lecanii, the population of sucking pests remained on lower side. The results clearly indicated in the treatment where Imidacloprid 17.80SL was sprayed continuously with or without the seed treatments either with imidacloprid tows or with thiamethoxam 35 FS certainly caused sucking pests resurgence. The significant enhancement in the population of pests in the respective treatments might be due to growth advantage caused by imidacloprid application. Phytohormone which induced significant changes in morphophysiological traits that ultimately resulted in increase in sucking pest incidence in the respective treatments. The observations obtained are corroborating with the findings of ${ }^{[2]}$, who reported the dramatic changes in the morphophysiological traits in cotton plants when sprayed with Trimax which contains Imidacloprid 17.80SL as an active ingredient that belongs to the class chloronicotinaide.

\section{References}

1. Abdul Baki, A. A. and Anderson, J. P., 1973, Vigour determination in soybean seeds by multiple criteria. Crop Sci., 13: 630-633.

2. Anonymous, 2005, All India Co-ordinated Cotton Improvement Project. Annu. Rep. 1: 6-8.

3. Bajaj, B. S. and Ghosh, A. K. 1975, Antifungal antibiotics in perspective. In: Advances in Mycol. Plant Pathol. Sagar Printers, New Delhi, pp: 279302.

4. Barrs, H. D. and Weatherly, P. E., 1960, A re-examination of relative turgidity for estimating water deficit in leaves. Australian J. Biol. Sci., 15: 413-428.

5. Elliot, R. H., Mann, L. W. and Labun, T., 2011, Impact of thiamethoxam seed treatment on flea beetle damage, vigour and performance of canola, Brassica napus. Global Forum on the Vigor Effect of Cruiser, Ho Chi Minh City, Vietnam, November, 2011:pp-8.

6. Evangelos, G., Derrick, M. O. and Androniki, B., 2004, Cotton plants response to $\operatorname{Trimax}^{\mathrm{TM}}$ insecticides foliar application and increasing temperature. Summaries of Arkansas Cotton Research.

7. Ferre, D. C. and Hall, F. R., 1978, Effect of growth regulators and multiple applications of pesticides on net photosynthesis and transpiration of greenhouse grown apple trees. J. Am. Soc. Hort. Sci., 103: 61-64.

8. Ferree, D. C., 1979, Influence of pesticide on Photosynthesis of crop plants. Photosynthesis and Plant Develoement.: 141-331.

9. Hennouni, N., Djebar, M. R. and Djebar, B. H., 2002, Effect of systemic fungicide (combination of cyproconozole and propiconazole) newly introduced in Algeria on Septoria of two varieties of 
wheat (Triticum duram Desf). Adv. Environ. Biol., 6 (4): 1433-1441.

10. Karasichdova, G. V., Asoeva, L. M., Gillar, Y. E. and Singinov, B. S., 1989, Photosynthetic system of $G$. barbadense at early stages of development. Doklady vsesovaznoi ordena Trudovogo krasnogo Znameni Akademii Sel Skokhozya irtvennykh Nauk Imen V. I. Lenina. 12: 9-11.

11. Patil, B. C., Patil, S. B., Udikeri, S. S., Adarsha, T. S. and Khadi, B. M. 2003, Effect of Imidacloprid 0seed treatment on growth, yield, seedling vigour and biophysical parameters in cotton (Gossypium spp.) genotypes, World Cotton Research Conference-3, Cape
Town- South Africa.

12. Udikeri, S., Kranthi, S., Kranthi, K. R., Vandal, N., Hallad, A., Patil, S. B. and Khadi, B. M., 2011, Species diversity, pestiferous nature, bionomics and management of mirid bugs and flower bud maggots: The new key pests of $\mathrm{Bt}$ cotton. Paper presented in World Cotton Research Conference on Technologies for Prosperity Pakistan, November 15, pp. 203-209.

13. William, R. M. and Paulo, C. C., 2011, Thiamethoxam: Molecule moderator of growth, metabolism and production of spring wheat. Pecti. Biochem. Physiol. 100: 299-304.

\section{How to cite this article:}

Vijayakumar Savanur, S.B. Patil and Ganesha Halikatti. 2018. Effect of Seed Treatment and Sprays Formulations on Morpho-Physiological Traits of Bt Cotton and their Impact on dynamics of Sucking Pests. Int.J.Curr.Microbiol.App.Sci. 7(07): 3994-3999.

doi: https://doi.org/10.20546/ijcmas.2018.707.465 